\title{
Modernism, Celebrity and the Public Personality
}

\section{Rod Rosenquist}

This is the peer reviewed version of the following article: Rosenquist, R. (2013), Modernism, Celebrity and the Public Personality. Literature Compass, 10: 437-448, which has been published in final form at http://onlinelibrary.wiley.com/doi/10.1111/lic3.12064/full. This article may be used for non-commercial purposes in accordance with Wiley Terms and Conditions for Self-Archiving.

Wherever possible, please read and cite from the published version.

\begin{abstract}
This article takes for its subject the complex relationship between modernist literature and the celebrity system of values arising in the late nineteenth century and hitting its ascendancy in the early twentieth. A wide range of scholarly work in the field is surveyed, particularly those investigating modernism within contexts of celebrity, promotional culture and value. The article aims to break down the relationship between modernism and celebrity into two major component parts - first, the self-authoring and promotional side of modernism and, second, the reception of modernism within a celebrity-culture framework, whether through the institutions, the media or the audience that make modernist figures into 'public personalities'.
\end{abstract}

\section{Modern Celebrity and Celebrity Modernism}

Though interest in famous people is as old as recorded history, the idea of celebrity appears as a more recent refinement. Whereas one earns fame or infamy through ones words or actions, celebrity can be defined as a kind of renown entirely distinct from whatever renders that person known in the first place. Or as Daniel J. Boorstin first asserted, 'The celebrity is a person who is known for his [or her] wellknownness' (57). Celebrity culture therefore signifies this system of values whereby an individual achieves well-knownness, which, regardless of merit, is often fashioned in terms of publicity, mediation and a quasi-mystical scale of promotional value, becoming a public personality.

Putting it in these terms, the connection between modernist studies and celebrity culture may not be immediately apparent, particularly if one's perspective of modernism is coloured by early representations of the movement as centred on high art, autonomy and elite culture. If the celebrity system depends not 
upon merit but upon representation in mass media and popular culture, modernism has historically been considered its opposite. But since the late 1990s, the work of the new modernist studies has been systematically interrogating the 'great divide' between high art and mass culture, revealing the points of intersection between modernism and literary institutions, the mass market and the public. Two collections of essays on the modernist investment in markets and promotional culture appeared in 1996, one edited by Dettmar and Watt, the other by Willison, Gould and Chernaik, followed by further enquiries into how modernism was branded, promoted and sold by Wexler and Rainey. These joined earlier work on modernism's troubled relationship with mass culture, including volumes by Wicke, Naremore and Brantinger, Strychacz, Tratner and of course Huyssen's introduction and elaborations on 'the great divide'. ${ }^{1}$ These interventions in the prevalent representation of modernism as autonomous and detached from market economies set the stage for a new materialist turn in modernist criticism and provided the framework in which the relationship between modernism and celebrity might be reconsidered. Building on theoretical work by Foucault, Bourdieu and Horkheimer and Adorno, as well as an emergent strand of celebrity studies, led by Dyer, Braudy and Marshall, a number of modernist scholars turned their attention to the interplay of promotional culture, mass media and modernist aesthetics.

What is perhaps most compelling is the corresponding trajectories of the histories of modernism and celebrity culture. Both make their first substantial appearances in the latter half of the nineteenth century, reaching their peak in the first half of the twentieth century while engaging with new forms of technology, mediation and mass consumption. Celebrity and modernism develop in tandem largely through modern developments like increased urbanisation, through the introduction of technologies, including cinema, radio and other global communications, but also through new patterns and manipulations of communication flow. As books by Cutler, Wollaeger and Ardis and Collier have shown, this included developments in a range of journalistic, entertainment, political and commercial channels of communications, with modernist techniques and initiatives mirroring the mass cultural developments and providing, in the words of Wollaeger, 'mechanisms for coping with information flows' (xiii). In the period 1910-1945, as celebrity culture reached its ascendancy, it becomes clear that the modernists were also engaging many of the cultural forces that were making self-promotion possible within new markets and across new media. The relationship of modernism to celebrity is built on this shared platform of emergent mass markets and methods of communication which develop in the late nineteenth and early twentieth centuries, and centre on perceptions of the artist or author as notable figure within these new networks of promotion, publicity and mass reception. While the modernist author would typically be

\footnotetext{
${ }^{1}$ As well as Huyssen's After the Great Divide: Modernism, Mass Culture, Postmodernism (1986), one should not ignore the 2002 recontextualising of his argument in light of the materialist turn in modernist studies, 'High/Low in an Expanded Field', published in Modernism/modernity.
} 
framed (often framing themselves) by a rejection of mass culture in their own work, a study of celebrity systems of value reveals very similar movements within promotional culture led to their eventual success within the cultural field.

Aaron Jaffe makes this idea central to his first chapter of Modernism and the Culture of Celebrity, quoting Pound's letter to Eliot's father in which the poet's confidence is asserted that one did not have to write 'popular fiction' to earn a living in the age of literary modernism, but could exist 'with some comfort' on the production of 'unpopular writing' (18). This is possible due to the modernist poet's ability to draw on the institutions, periodicals and other emergent markets for culturally elite works; but it is also because, in a promotional culture, there are ways of publicizing and marketing oneself as a trademark or brand within these networks without having to rely on large sales. While these ideas were admirably demonstrated by scholars in the 1990s, Jaffe offers a new approach; he labels this self-promotion via the trademarked authorial name an 'imprimatur', relating it to the contemporaneous celebrity culture. Jaffe writes, 'At once a distinctive mark and a sanctioning impression, the imprimatur, as I define it, turns the author into a formal artifact, fusing it to the text as a reified signature of value' (20). While modernists may devalue their own personality (as Eliot's 'Tradition and the Individual Talent' suggests) and produce obscure and difficult texts not easily accessible to a common public, Jaffe's celebrated author still produces 'a moment of clarity to all takers' that the work is underwritten by their own unique signature of authorial value. This stylistic watermark, regardless of who reads (let alone who understands) the text on the page, promotes the modernist author as celebrity figure. Many modernists can be found engaging in this kind of authorial self-fashioning and the painstaking construction of careers. But it is not only the selffashioning, the immersion in subjectivities and individuality, that brings modernism into conversation with celebrity; there is also what Jaffe calls, after Walter Benjamin, the 'afterlives' of their works: the reception, the reputations and the name-value that their works and their selves produce. Along with the modernist production of exceptional author-figures, the consumption of celebrity modernists becomes just as central a concern for the theorist of modernism and celebrity.

Alongside the emergence of new modernist studies, with its focus on material cultures and the crossing of the great divide, a number of critics have begun to explore modernism's engagement in promotional culture from the perspective of celebrity. ${ }^{2}$ With so much attention focused on modernism and celebrity

\footnotetext{
${ }^{2}$ Early interventions in this area include work by Leonard J. Leff, Nancy Armstrong, Brenda Silver and Kirk Cornutt. Fuller explorations of the production of celebrity value in modernist cultures were produced by Loren Glass's Authors lnc. (2004) and Aaron Jaffe's Modernism and the Culture of Celebrity (2005), followed by Faye Hammill's Women, Celebrity and Literary Culture Between the Wars (2007). Additional interpretations were added by Karen Leick, Jonathan Goldman and Timothy Galow, as well as the contributors to a collection of essays, Modernist Star Maps, edited by Jaffe and Goldman. These volumes can be further contextualised through work by David Chinitz, Sean Latham and Judith Brown, to name but a few.
} 
since 1997, picking up pace since 2004, it is clear that the vexed relationship between high modernist culture and the system of celebrity emerging simultaneously provides a rich field for consideration of how elite culture relates to mass audiences. This essay will first examine the modernist approach to selffashioning, engagement with personality and personae and understanding of the role of an author. But the lesson from celebrity theory is that it takes more than an individual to produce celebrity value, and the second section will examine the reception of modernism and the afterlives of the modernists themselves, to understand how far modernism's institutions, media and audience were influenced by celebrity culture in mediating or receiving the modernist movement and its most notable texts. Building on the groundwork provided by the new modernist studies, we can now recognise that many modernists went beyond simple self-promotion, networking or engagement with mass-cultural modes of communication. In fact, the aesthetic of modernism is found to be deeply embedded in a system of values associated with promotional culture or celebrity. In the coming pages, we will examine how the artist's role in the production of art is foregrounded by style or technique during the modernist period, how the authorial signature transforms the artist into a trademark or a brand and how cultural institutions and audiences including those who perhaps make no sense of the work of art itself - help to sustain the celebrated aura of the exceptional individual as a public personality.

\section{The Modernist Author as Public Personality}

The idea of making personality public would have been abhorrent to many modernists. The version of modernism framed by T. S. Eliot's influential essay, 'Tradition and the Individual Talent' (1919), continues to promote an idea of impersonality and freedom from personal emotion in modernist poetics. Ezra Pound openly agreed with this view, following Yeats and Wilde in preferring the mask or the persona to the intimately personal poetic stance. All the same, the projection of a persona can correspond closely to the celebrity system of value, as the projection of a public personality is clearly not always identical to the individual person behind any given celebrity. In the context of Eliot's essay, in fact, one wonders whether the desire for 'the extinction of personality' is not actually a desire to extinguish the personal in order to better project a public personality, as Eliot's own poetry seems to suggest. 'The Love Song of Alfred Prufrock', after all, asserts that 'there will be time / To prepare a face to meet the faces that you meet' (4), a clear evocation of the demands placed on individuals to project a personality before a public. In the end, this production of a subjective personality forms a key feature of modernist poetic and narrative techniques: consider Eliot's assertion that it is not in 'personal emotion' that an author is 'remarkable' but through the power to transform emotion into an experience ('Tradition' 21); or Woolf's presentation, in 'Mr Bennett and Mrs Brown', of a familiar kind of anonymity in her hypothetical Mrs 
Brown, making her a kind of recognizable nobody who is positioned, according to Jaffe and Goldman, on 'the jagged edge between oblivion and ubiquity: a celebrity for everybody' (5).

Of course not every modernist agreed with Eliot's theory of emotionless and impersonal poetry; in fact, as suggested previously and further detailed below, even Eliot appears to promote the presentation of a public personality. This idea of the production of a 'Public Face of Modernism', to borrow the title of Morrisson's book, has recently been examined by Rochelle Rives. Though the article does not specifically speak of celebrity, a number of modernists (including Mina Loy and Henri Gaudier-Brzeska) are revealed to be intently focused on the power of the individual in conveying and promoting personality through a projection of a public face. To put it another way, the idea of 'the making of face', as Rives terms it, is fundamentally modernist while simultaneously bringing modernism face to face with the promotional or celebrity culture of mass markets emerging in the period. Many of the key genres and characteristics identified with modernism, in fact - the Bildungsroman, the autobiography,stylistic innovation, subjectivity, personality and the introduction of the author as character - all reveal the connections between the movement's aesthetic and the contemporary cultural structure of the celebrity field.

The role of the artist as subject in literary modernism is an important place to start, particularly through the lens provided by Foucault in 'What is an Author?'. By examining the work of Henry James, James Joyce and the trio of Upward, Isherwood and Waugh, Jaffe points to the modernist author-novel as a key component in the production of authorial value in the period, bolstering the idea of author as personality, imprimatur and ultimately cultural celebrity via promotion of 'the literary life' (21). Loren Glass in Authors, Inc. also takes up the idea of the author-as-subject narrative, revealing it is this choice that best captures the tension of the personal and the public, the individual and the masses, in the creation of the author as subject. Autobiography, a key genre in modernism, as Max Saunders and others have pointed out, perfectly sets up the story of the personal life engaging the collective - the story of the self and the tale of the tribe at once, or, as Mutlu Konuk Blasing says, 'Since autobiography thus bridges public and private life, the hero of autobiography is the paradoxical private-person-as-public hero' (Glass 7). Glass makes a convincing argument that the emerging interest in this paradox is at the heart of modernism and helps to define its relationship with celebrity. He writes,

This stubborn fascination with the possibility that the name [of the three-fold author, narrator and protagonist structuring the autobiography], in the end, must somehow mandate a referential relation between the private consciousness from which writing emerges and the public sphere in which it circulates undergirds the culture of authorial celebrity (8).

This helps to frame the connection between modernism and self-fashioning, and subsequently between the self-fashioning of the personal and its public image, a chain which draws the world of elite and 
individualist writers into the public gaze of celebrity culture. Glass comments on the irony of Eliot's call for an impersonal poetics in 'Tradition and the Individual Talent' while producing a persona and displaying 'high-priestly charisma' that became intimately associated with his critical and poetic work as he grew increasingly famous. David E. Chinitz in T. S. Eliot and the Cultural Divide takes this one step further, analyzing Eliot the celebrity and remarking,

Indeed, one of the many paradoxes of Eliot's career is that it was the austere and aloof elitist, and not the low-comedy or Raymond Chandler enthusiast, that became the public face of his own celebrity. It was, in other words, Eliot at his furthest remove from popular culture who became a popular figure (174-5).

This is an important conclusion to reach for understanding the difference between a study of modernism's engagement with mass culture and a study of modernism's engagement with celebrity, as much as they may overlap. The name T. S. Eliot, Chinitz points out, came to signify a high-cultural, traditionalist public persona rather than the man who appreciated Marie Lloyd and ribald humour. Nor did Eliot seek to hide his affection for popular culture, which suggests more attention must be paid to how such cultural constructions come about (as will be done in the next section). But what is most interesting, perhaps, is that Chinitz finds just how far Eliot's public persona allows him to go on being an impersonal poet, saying,

This persona, Eliot's face of celebrity, would serve him well for the remaining thirty-two years of his life: it offered him a kind of privacy screen behind which his growing public, enjoying the spectacle before them, would not wish to pry (176).

In this way, Eliot was able to maintain his personal life while promoting his impersonal poetics through his public personality. British Pathé archives reveal this with unused footage for a newsreel of 'Personalities of the Day' in 1949, with Eliot, stationed before a fireplace in a lecture room, addressing the public gaze and the watching camera with a calm and formal manner ('People in the News'). In fact, Eliot becomes a celebrity face for modernism itself, dressed in his three-piece suits, giving lectures and making public pronouncements, but also spending considerable time in the promotion, publication and personal support of the less-public authors engaged in modernist literary innovation. Or as Glass says, 'For Eliot, the exceptional personality [the celebrity] is the necessary condition for the escape from personality,' going on to add, 'For modernist artists, personality in the biographical sense tended to be sublimated into the concept of "style"" (6).

Jaffe makes literary 'style' the other major hallmark of the imprimatur. Following Fredric Jameson's observation that modernism is 'predicated on the invention of a personal, private style, as unmistakeable as your fingerprint, as incomparable as your own body' (6), Jaffe points to how a unique literary 
technique - personal and private, though it may be - becomes part of the trademark of the modernist author, underwriting and promoting the cultural value of the work produced. Following Jaffe's lead, Jonathan Goldman's Modernism is the Literature of Celebrity argues that the characteristics now associated most obviously with literary modernism - particularly subjectivity, impersonality and stylistic technique - are borne out of the desire of modernist authors to engage the celebrity culture embedded in the system of cultural production they themselves were part of. Early modernists, in many ways, show themselves to be modernist through their promotion of themselves as authors. Goldman uses Oscar Wilde just as Jaffe uses Henry James to reveal the extent to which these early modernists staged themselves as author-figures, undermining the received notions of individuality at the time, namely that each body contained and underwrote the true identity of each person. Wilde's lecture tour of America in 1882, Goldman shows, was only the beginning of a career focused on the presentation of a public face that has little to do with a presumed personal identity.

But it is with the high modernists that Goldman makes his most compelling case that modernist literature, and not just modernist culture, is connected intimately to celebrity culture. Goldman makes the case that the literary technique of promoting an authorial style in itself leads to this celebration of the modernist writers. For example, A Portrait of the Artist as a Young Man (1917) first promotes a theory often associated with Eliot's impersonality, that the artist 'remains within or behind or above his handiwork, invisible, refined out of existence, indifferent' (215). But the novel, as Jaffe had also argued, simultaneously calls attention to its author through a promotion of the semi-autobiographical artist/aesthete behind the novel and through the introduction of an innovative literary technique driving the narrative. Many critics, it should be pointed out, jump to the conclusion that Stephen Daedalus's statement regarding the invisible author is Joyce's own, a presumption that underlines both how closely the author of $A$ Portrait is taken to be its own subject while also confirming just how visible to the public gaze Joyce, the author, actually is - no matter what Stephen may say.

Joyce's Ulysses (1922) takes this a major step forward, foregrounding a new literary style or technique in each successive chapter while narrating the story of the fairly humdrum day suffered by the protagonist, Leopold Bloom. The question must be asked, then, as Goldman does implicitly, who is the real protagonist of Joyce's novel if not Joyce himself? In fact, the modernist use of style is, like autobiography, another form of authorial self-fashioning. Goldman says, 'The stylistic changes in Ulysses, by continually asking readers to guess Joyce's extradiegetic rationale for that change, create the idea of the author' (61-2). The readers are encouraged specifically to read the author as much as to read the story - evidence backed up by the central role played by Joyce's schematic structure (Homeric parallels and associations for each episode, including symbol, colour, organ of the body and technique) in 
the reception of the novel from its earliest publication. This is not meant to diminish appreciation of the text itself. Yet a full understanding of Joyce's novel requires clear sight of the celebrity context - how far Joyce the author colours the novel by his presence, somewhere 'within or above or behind his handiwork.' As Goldman says, 'This manipulation of the reading process makes style the trademark of the author and validates Joyce's claim to originality by serving notice that one exceptional individual produced the book' (63).

\section{The Public's Modernism: Mediation and Reception of Celebrity}

Gertrude Stein figures in many studies of modernism and celebrity, representing both the relative height of high modernism and the complete presentation of a public personality - a true celebrity of the modernist period in both elite and mass cultural terms. While Jaffe, Glass and Goldman all discuss her authorial presentation and reputation, her celebrated style and her network of celebrity associates, Stein is equally fascinating in illustrating modernism's engagement with celebrity from the perspective of the mass audience - where a projection of authorial personality ceases to be personal and enters the public domain. At the beginning of the 1930s, for example, Stein was still struggling to find publication for each of her highly stylized and obscure pieces of work. With the publication of The Autobiography of Alice B. Toklas, she found herself the author of a bestseller, with requests for material coming in from publishers and widespread media attention. By the time of her lecture tour of America, she was an A-list celebrity, featuring in newspapers, on radio and in newsreels, selling out lecture halls and being asked for her autograph. It was a confusing and disorienting experience for a high modernist. On seeing her name in lights in Times Square, she began to question her identity and value - not her promotional value, which had never been higher, but the value of her work, which she found increasingly ignored in the shadow of her own personality. ${ }^{3}$ Stein begins to muse on how far identity and personality belong to the individual and how far it is made up by mediated images and the public that consumes them. She wonders at the American public 'being more interested in you than in the work you have done although they would not be interested in you if you had not done the work you had done' (Stein 93). Though she does not use the word, Stein reflects on how she ever became a celebrity in the first place, if not due to readers embracing her work - how she became known for being known rather than renowned for her literary endeavours as she wished to be.

\footnotetext{
${ }^{3}$ These questions, as well as Stein's narration of her witnessing her own celebrity, can be found in Stein's second memoir, Everybody's Autobiography (1938).
} 
This decade-long trajectory leads many to consider The Autobiography of Alice B. Toklas as the start of Stein's fame, making her a celebrity. But in the most in-depth study of Stein's celebrity to date, Karen Leick makes the case that Stein's celebrity began to appear long before this bestselling volume. It is probably true that, insofar as her self-staging goes, Stein's first autobiography (closely followed by the subsequent lecture tour) was the first time she willingly promoted her personal life for consumption by a mass audience. But as Leick shows, Stein's early, experimental works led to widespread intrigue, particularly by the American press, as the media sought an answer to questions about her sincerity, her sanity, her intentions and the strangeness of her writings. ${ }^{4}$ Without always encouraging readers to pick up Stein's obscure publications, writers in the press presented her as a curious personality - perhaps a mysterious genius or a perpetrator of a hoax - and her public personality was already taking on its celebrity value. What happened in the 1930s was perhaps a natural extension of this rather than its cause. Leick offers an important correction to those who, like Lawrence Rainey, claim that the high sales of The Autobiography of Alice B. Toklas made Stein a household name, instead revealing that Stein's household name prompted the public to make the book a bestseller (8) - a key distinction in understanding the nature of celebrity, where being known is not always based on merit or, in the case of authors, on being read. As Robert Coates in The New Yorker would point out as early as 1931 (the year before The Autobiography), 'One thing that has always amused me about Miss Stein is that she is more often talked of, argued about, than almost any other writer today by people who have never read a line of hers' (Leick 135). This perhaps says as much about her celebrity as the success of her lecture tour in 1934-35 and shows how far her work secured her celebrity, by reputation, even before she was writing self-fashioning, highlycelebrated books like The Autobiography.

Thus far, we have examined actions taken by modernist writers in order to promote the artist as worthy of celebrity. But now we must turn our attention to the modernist celebrity culture that was entirely beyond the agency of the modernists themselves. For example, what are we to make of the public personality of modernist artists once they are no longer alive - a question raised by Aaron Jaffe in " $\mathrm{T}$. S. Eliot rates socko!": Modernism, Obituary, and Celebrity', an essay intent on 'exploring what happens to modernist celebrity beyond its death drive' (424). Once more, it is clear just how far the trademarks and legends of a modernist author - of 'T. S. E.', in this case - are promoted, in print, after the poet's death, in a manner formulated perhaps as much out of the public's demand for celebrity personality as out of the poetry's merit or out of a critical reputation built up through cultural institutions. But Jaffe makes clear this is part of the nature of celebrity, particularly at the moment of death, when the living celebrity passes into pasttense reflections, and the reputation is first organised entirely notionally. He argues,

\footnotetext{
${ }^{4}$ Also see Leonard Diepeveen's chapter, 'The Newspaper Response to Tender Buttons, and What It Might Mean', in Transatlantic Print Culture, edited by Ardis and Collier.
} 
Reputation is overburdened from the start by conditions of decay, and, despite the exaggerated posing of artistic consciousness in the production of modernist texts - or because of it - a modernist reputation presents itself in places of consumption beset by its own devaluation (424).

The question of celebrity valuation, however, surely works both ways, inflating and deflating according to different scales of value and reputation (eg, high vs. low), even at the moment of the celebrity's death. The transition is really one from a sphere in which an author still has some agency in the formulation of their own celebrity into one in which the mediated and received celebrity is all there is. For T. S. Eliot, his ascendancy in terms of cultural value during the modernist period had largely disappeared by the time of his death in 1965, with a consequent devaluation as cultural tides shifted.

But other modernists, without such levels of cultural capital or high-art posturing yet with equal celebrity value, watched their own agency disappear during their own ascendancy, as illustrated in Faye Hammill's Women, Celebrity, and Literary Culture Between the Wars. Female middlebrow authors of the early twentieth century, including Anita Loos, Stella Gibbons and Dorothy Parker raise questions as to "what kind of agency did women writers have in the determination of their own celebrity images, and how far were they appropriated by the media into particular cultural discourses?' (Hammill 3). This is surely the double-edged sword of celebrity, in any cultural system: that in promoting oneself and projecting a personality to the level of public fame, the celebrity is given a platform and a voice from which to advance their cause; but the celebrated author also loses control of the image, ceding their personality to the media and ultimately the public. In the case of middlebrow modernism, authors often felt forced to fit the picture created for them by the media or demanded of them by their readers - as seen, for example, in L. M. Montgomery's publicity photograph sent by the publishers to adoring fans, portraying the author at her writing desk, 'rapt in inspiration - apparently', as she herself so dubiously describes it (Hammill 105). Yet as institutional frameworks for modernism within promotional culture have begun to be thoroughly explored in connection to celebrity, the role of readers in the formation of a celebrity culture connected to modernism has really only been implicitly engaged. While it can be argued that the public image projected by Joyce, Eliot or Hemingway had much to do with their own self-styling, or that Stein's work was celebrated primarily in the media rather than by her few select readers, it is true that there can be no celebrity, no public image built for mass consumption, without an audience ready to consume it. Michael D. Garval's chapter in Modernist Star Maps explores the complicated relationship between the exceptional individual and the attendant mass audience, this time from the point of view of an early modernist author who was himself the celebrity consumer: Jean de Tinan. The remains of Tinan's lost 'Essay on Cléo de Mérode Considered as Popular Symbol' provide a fruitful portrait of the role that the public played in the formation of celebrity, even in the high-cultural world of dance from which Mérode 
emerged. It also hints at an idea that might be called the affect of celebrity: how celebrity is not only a result of self-promotion or mediated public images, but stems as much from a shared sense of feeling on the part of the public. Tinan's protagonist in the novel, Think Success! (1897) muses on the fickle nature of celebrity in relation to the dancer and famous beauty: 'Everything is immortal - at least for a while; and this morning Mlle Cléo de Mérode strikes me as particularly immortal' (Jaffe and Goldman 145). ${ }^{5}$ Later, Garval summarises Tinan's description of the process as 'the media supplies an image, brought to life through countless fans' collective gaze. The multitude votes with its eyeballs, electing Mérode its idol' (145). It is the crowd that makes a celebrity, for Tinan, rather than the self-authoring or the media, which can at best nominate the celebrity as ready for consumption. Tinan goes on: 'To make sense of mass celebrity, you need to figure out what the crowd is thinking, plumb its "collective soul" (147). Even at the end of the nineteenth century, then, it is clear that the public retains its own agency in selecting its adored celebrities and in promoting them, and the intuition, emotion and sentiment of the 'collective soul' forms an important source for understanding modernist celebrity.

The complex structure of celebrity culture should be growing clearer, with value being generated from a mixture of artistic self-promotion, institutional mediation and audience reception. It is for this reason Aaron Jaffe in Modernism and the Culture of Celebrity distinguishes between the 'upstream' and the 'downstream' of cultural production, describing the creation of the imprimatur (the upstream) in his first chapter, but going on to explore authorial 'afterlives' (the downstream) in his second chapter. Focusing on the adoption of the author's name as adjective, he points out that 'Poundian', 'Joycean', 'Woolfian', 'Yeatsian' and 'Lawrentian' are all in the Oxford English Dictionary (61). But what are the definitions for these new adjectives? Jaffe does not quite say they are hollow celebrity markers, names of those known only for being known, but he does point out that the $O E D$ does not make any distinction between that which is Poundian from that which is Lawrentian, or for that matter that which is Shakespearean. In other words, the Eliotic (which does not make the $O E D$, for whatever reason) is simply that which demonstrates the qualities espoused or illustrated by T. S. Eliot. But the qualities of such a concept is entirely left up to the reader, whether experienced or inexperienced in Eliot's life and work - and becomes a representation and eventually a source of literary valuation. The use of the adjective 'Eliotic', in other words, allows a reader to demonstrate their own critical qualifications (earned or not) by invoking the poetic or critical qualifications of Eliot himself, an abstract (and closed) system of value established neither by writer nor reader entirely but by the leveraging of both sides of the celebrity economy of values against each other. Or, we could say, the idea of Eliotic thought or verse is built entirely into the

\footnotetext{
${ }^{5}$ Interestingly, Tinan's protagonist is also writing an essay entitled 'Essay on Cléo de Mérode Considered as Popular Symbol', the same title of Tinan's lost essay - though as Garval makes clear, whether the essay was ever finished is subject to debate.
} 
reception of that which Eliot stands for in the public image of him, rightly or wrong, whether built on merit, reputation or mere fancy.

Wyndham Lewis foresaw this moment, even while modernist reputations and canonical values were still developing. He would prophecy in his first of two autobiographies about the power names would hold in the histories of the time, "strange shapes labeled "Pound", "Joyce", "Weaver", "Hulme". With an egoistic piety I have made it my business to preserve in these pages something of the first-hand reality' (Blasting and Bombardiering 254). Lewis battles against future historians and biographers, trying to maintain some authenticity of personality and artistic production against the inflation and corruption of literary reputation and celebrity culture. But he, like many memoir writers of the period, was himself engaged in the celebrity system simply by choosing to promote the names that helped to sell books. Lewis's primary goal in writing his memoir was sales, and the public's hunger for literary celebrity gossip, he knew, could provide that. But in an unused preface to his autobiography, addressing his readers directly, he makes clear how little he relishes his task, writing: 'I am about to gossip. I am going to be exceedingly 'personal' about certain persons. But this is not at all because I wish to be. It is because of you that I descend to these picturesque details' ('Preliminary Aside' 183). Lewis clearly lays the blame on the readers for the celebrity culture he himself was helping to promote, and other memoirists (Robert McAlmon, in particular) shared a sense of regret at the literary reputations they themselves were helping to inflate so that a hungry middlebrow or mass readership might learn more about the public personalities presented by modernist writers and artists. ${ }^{6}$

\section{Conclusion}

Perhaps one can summarise the intricate relationship between celebrity production via artists, authors, institutions, media and the public with a final example: Marcel Duchamp's Fountain. This significant piece of ready-made sculpture, signed and dated 'R. Mutt 1917', has produced major influence on modern and contemporary art, but also calls attention to the important ways modern art and celebrity culture have gone hand in hand. Duchamp's piece took little artistic labour to create, having been simply purchased, signed and displayed. But the act of transforming the ready-made from practical object to work of art calls attention to the artist as exceptional individual, capable of redefining objects, concepts and philosophies of art. Duchamp is now enshrined in art history, with Fountain one of his best-known works. But being 'produced' by an exceptional individual was not enough, as Fountain, for its impact, required a pedestal, an exhibition by the Society of Independent Artists and an audience. The work might

\footnotetext{
${ }^{6}$ For more on modernist autobiography and the consumption of literary personality, see my chapter in Incredible Modernism: Literature, Trust and Deception.
} 
not have had such influence if there had not been the attempt to suppress the display of the work of art by those running the exhibition, or the cries of protest arising from the press - first against this attempted suppression in, for example, The Blind Man and later by those who considered the work less than art, a hoax or even offensive. Those members of the public who spoke for or against the work of art, who praised or denounced it, whether from a high culture or mass public, helped to formulate Duchamp's celebrity and effectively canonize the object, which shows that, unlike fame, which has its opposite (infamy), celebrity - like modernist art - exists on a separate scale of value, irrespective of labour, merit, culture or social use.

Duchamp, Joyce, Eliot, Stein and Picasso are brand names or trademarks that all come to signify something more than the individual works they produced. Work in the field of modernism and celebrity culture reveals how these celebrity values arise from two sources: first, from modernist techniques and aesthetics themselves, the imprimatur left by their self-fashioning efforts; second, through the mediation of promotional networks and institutions and the interests of the public in consuming celebrity. There is more work to be done in this area, from promotional networks and name-associations, from literary gossip columns to press reviews and advertisements, from modernists sometimes marginalized by gender or race who were otherwise celebrated, such as middlebrow women writers or those associated with the Harlem Renaissance. More work needs to locate modernism's readership and the role of the public in the ascendency of modernist values and literary positioning, as well as how celebrity promotional values relate to modernist theories of personality and impersonality. Wherever modernism is produced, is promoted or meets its public, there arise questions as to the relationship between private and public, between individual and collective, between personal agency and public personality, and it is the cultural system of celebrity values and power relationships that provide a key framework for this debate.

\section{Works Cited}

Ardis, Anne, and Patrick Collier, ed. Transatlantic Print Culture 1880-1940: emerging media, emerging modernisms. Basingstoke: Palgrave Macmillan, 2008.

Armstrong, Nancy. 'Modernism's Iconophobia and What it Did to Gender.' Modernism/Modernity 5.2 (1998) 47-75.

Boorstin, Daniel J. The Image: A Guide to Pseudo-Event in America. New York: Harper \& Row, 1961. 
Bourdieu, Pierre. The Field of Cultural Production: Essays on Art and Literature. Ed. Randal Johnson. New York: Columbia University Press, 1993).

Braudy, Leo. The Frenzy of Renown: Fame and Its History. Oxford: Oxford University Press, 1986.

'People in the News aka Personalities of the Day, 1949'. British Pathé archives. $<$ http://www.britishpathe.com/video/people-in-the-news-aka-personalities-of-the-day/>

Brown, Judith. Glamour in Six Dimensions: Modernism and the Radiance of Form. Ithica, NY: Cornell University Press, 2009.

Chinitz, David. T. S. Eliot and the Cultural Divide. Chicago: Chicago University Press, 2005.

Collier, Patrick. Modernism on Fleet Street. Aldershot: Ashgate, 2006.

Cornutt, Kirk. "Inside and Outside: Gertrude Stein on Identity, Celebrity and Authenticity". Journal of Modern Literature. 23:2 (Winter 1999/2000): 291-308.

Cutler, Edward S. Recovering the New: transatlantic roots of modernism. Hanover, NH: University Press of New England, 2003.

Dettmar, Kevin J. H., and Stephen Watt, ed. Marketing Modernisms: Self-promotion, canonization, rereading. Ann Arbor: University of Michigan Press, 1996.

Dyer, Richard. Stars. London: British Film Institute, 1998.

Eliot, T. S. 'The Love Song of J. Alfred Prufrock (1917). The Complete Poems and Plays, 1909-1950. San Diego, CA: Harcourt, Brace, Jovanovich, 1980.

Eliot, T. S. 'Tradition and the Individual Talent' (1919). Selected Essays (1951). London: Faber \& Faber, 1966. 13-22.

Foucault, Michael. 'What is an Author?' The Foucault Reader. Ed. Paul Rabinow. New York: Pantheon, 1984.

Galow, Timothy. Writing Celebrity: Stein, Fitzgerald, and the Modern(ist) Art of Self-Fashioning. New York: Palgrave Macmillan, 2011.

Glass, Loren. Authors, Inc. Literary Celebrity in the Modern United States, 1880-1980. New York: New York University Press, 2004.

Goldman, Jonathan. Modernism is the Literature of Celebrity. Austin: University of Texas P, 2011.

Hammill, Faye. Women, Celebrity and Literary Culture Between the Wars. Austin: University of Texas Press, 2007. 
Horkheimer, Max, and Theodor W. Adorno. Dialectic of Enlightenment. Trans. John Cumming. New York: Continuum, 1993.

Huyssen, Andreas. After the Great Divide: modernism, mass culture, postmodernism. Bloomington: Indiana University Press, 1986.

Huyssen, Andreas. 'High/Low in an Expanded Field.' Modernism/modernity 9:3 (2002) 363-74.

Jaffe, Aaron. Modernism and the Culture of Celebrity. Cambridge: Cambridge University Press, 2005.

Jaffe, Aaron. “"T. S. Eliot rates socko!”: Modernism, Obituary, and Celebrity.' A Companion to T. S. Eliot. Ed. David E. Chinitz. Chichester: Wiley-Blackwell, 2009. 423-35.

Jaffe, Aaron, and Jonathan Goldman, ed. Modernist Star Maps: Celebrity, Modernity, Culture. London: Ashgate, 2010.

Jameson, Fredric. The Cultural Turn: Selected Writing on the Postmodern, 1983-1998. London: Verso, 1998.

Joyce, James. A Portrait of the Artist as a Young Man. Ed. Seamus Deane. New York: Penguin, 2003.

Latham, Sean. The Art of Scandal: Modernism, Libel Law, and the Modernist Roman à Clef. Oxford: Oxford University Press, 2009.

Leick, Karen. Gertrude Stein and the Making of an American Celebrity. New York: Routledge, 2009.

Leff, Leonard J. Hemingway and His Conspirators: Hollywood, Scribners, and the Making of American Celebrity Culture. Lanham, Maryland: Rowman \& Littlefield Publishers, Inc., 1997.

Lewis, Wyndham. Blasting and Bombardiering: An Autobiography (1914-1926). Revised ed. London: John Calder, 1982.

Lewis, Wyndham. 'Preliminary Aside to the Reader; regarding Gossip, and its pitfalls.' Modernism/modernity 4.2 (1997): 183-6.

Marshall, P. David. Celebrity and Power: Fame in Contemporary Culture. Minneapolis: University of Minnesota Press, 1997.

McAlmon, Robert. Being Geniuses Together: An Autobiography. London: Secker and Warburg, 1938.

Moran, Joe. Star Authors: Literary Celebrity in America. London: Pluto Press, 2000.

Naremore, James, and Patrick Brantlinger, ed. Modernism and Mass Culture. Bloomington: Indiana University Press, 1991. 
Rainey, Lawrence. Institutions of Modernism: Literary Elites \& Public Culture. New Haven, CT: Yale, 1998.

Rives, Rochelle. 'Modernist Prosopopoeia: Mina Loy, Gaudier-Brzeska and the Making of Face'. Journal of Modern Literature. 34:4 (Summer 2011): 137-159.

Rosenquist, Rod. 'Trusting Personality: Modernist Memoir and Its Audience.' Incredible Modernism: Literature, Trust and Deception. Ed. John Attridge and Rod Rosenquist. Farnham: Ashgate, 2013.

Saunders, Max. Self-Impression: Life-writing, Autobiografiction, and the Forms of Modern Literature. Oxford: Oxford University Press, 2010.

Silver, Brenda. Virginia Woolf Icon (Chicago, University of Chicago Press, 1999).

Stein, Gertrude. Everybody's Autobiography. Cambridge: Exact Change, 1993.

Strychacz, Thomas F. Modernism, Mass Culture, and Professionalism. Cambridge: Cambridge University Press, 1993.

Tratner, Michael. Modernism and Mass Politics: Joyce, Woolf, Eliot, Yeats. Stanford, CA: Stanford University Press, 1995.

Walker, John A. Art and Celebrity. London: Pluto, 2003.

Wexler, Joyce Piell. Who Paid for Modernism?: Art, Money, and the Fiction of Conrad, Joyce, and Lawrence. Fayetteville: University of Arkansas Press, 1997.

Wicke, Jennifer. "Celebrity Material: Materialist Feminism and the Culture of Celebrity." Feminism, the Public and the Private. Ed. Joan B. Landes. New York: Oxford UP, 1998.

Willison, I. R., Warwick Gould and Warren L Chernaik, ed. Modernist Writers and the Marketplace. Basingstoke: Macmillan, 1996.

Wollaeger, Mark A. Modernism, Media, and Propaganda: British narrative from 1900 to 1945. Princeton, NJ: Princeton University Press, 2006.

Woolf, Virginia. 'Mr Bennett and Mrs Brown.' A Woman's Essays. Ed. Rachel Bowlby. London: Penguin, 1992. 